\title{
Climbing-fiber induced state transitions in cerebellar Purkinje cells are controlled by synaptic conductance changes
}

\author{
Jordan DT Engbers ${ }^{1 *}$, Hamish W Mehaffey ${ }^{1}$, Fernando R Fernandez ${ }^{2}$, Ray W Turner ${ }^{1}$ \\ From Nineteenth Annual Computational Neuroscience Meeting: CNS*2010 \\ San Antonio, TX, USA. 24-30 July 2010
}

Purkinje cells have been previously modeled as a system undergoing a saddle-node bifurcation of fixed points from rest to firing and a saddle homoclinic orbit bifurcation from firing to rest. In vitro, this dynamical structure is a result of the neuron's intrinsic membrane properties and is associated with bistability within a limited range of low firing frequencies, where a unidirectional climbing fiber (CF) input is able to toggle the cell between a firing ("up") and rest ("down") state. We identified several factors that contribute to bistability and the ability for a unidirectional input (CF) to toggle cell output, including a slow $\mathrm{K}+$ current activated during spike discharge or following synaptic depolarizations. However, input conditions that determine the probability for a Purkinje cell to express bistability in vivo have not been determined. A key difference in vivo is the presence of tonic background input to the dendrites from parallel fiber (PF) and stellate cell inputs. We tested the hypothesis that dendritic inputs control the dynamics of Purkinje cell firing, and can thus regulate the ability for CFs to induce toggling of Purkinje cell output.

Presentation of mixed excitatory and inhibitory dendritic current noise (I-noise) or conductance noise (g-noise) to a two-compartment 5-equation model of the Purkinje neuron had differing effects on spike output. Mixed Inoise increased the probability of observing CF-evoked transitions to a down state whether the model was in the low frequency-bistable regime or not. The size and time course of the currents associated with different state transitions suggested that properly timed PF and/or stellate cell inputs could affect the ability for CFs to invoke Purkinje cell transitions. However, conductance noise

* Correspondence: jdtengbe@ucalgary.ca

${ }^{1}$ Hotchkiss Brain Institute, University of Calgary, Calgary, Alberta, Canada, $\mathrm{T} 2 \mathrm{~N} 4 \mathrm{~N} 1$ prevented any CF-evoked transitions and the model was highly sensitive to the E:I ratio. Spike trains with physiological mean frequencies and high coefficient of variation $(\mathrm{CV})$ were also found. Spike triggered averages during g-noise revealed that the spikes were being driven by synaptic inputs and not intrinsic dynamics, indicating a shift in computational properties between high and low conductance states.

\section{Conclusions}

Here we show that bistability in a Purkinje neuron can be controlled by the amount of synaptic input it receives. Of the two types of noise we used, I-noise could cause spontaneous state transitions, but g-noise could not, suggesting that CF-associated toggling would not occur in high conductance states. These results could explain the discrepancy between in vivo and in vitro recordings regarding CF-induced state transitions.

\section{Author details}

'Hotchkiss Brain Institute, University of Calgary, Calgary, Alberta, Canada, T2N 4N1. ${ }^{2}$ Department of Bioengineering, University of Utah, Salt Lake City, Utah, 84112, USA.

\section{Published: 20 July 2010}

\section{References}

1. Dean P, Porrill J, Ekerot CF, Jorntell H: The cerebellar microcircuit as an adaptive filter: experimental and computational evidence. Nat Rev Neurosci 2009, 11(1):30-43.

2. Westby GWM, Collinson C, Dean P: Excitatory drive from deep cerebellar neurons to the superior colliculus in the rat: an electrophysiological mapping study. Eur J Neurosci 1993, 5:1378-1388.

3. Tabareau N, Bennequin D, Berthoz A, Slotine JJ, Girard B: Geometry of the superior colliculus mapping and efficient oculomotor computation. Biol Cybern 2007, 97(4):279-292.

4. Patton P, Belkacem-Boussaid K, Anastasio TJ: Multimodality in the superior colliculus: an information theoretic analysis. Brain Res Cogn Brain Res 2002, 14(1):10-19. 
5. Salinas $E$, Abbott LF: Invariant visual responses from attentional gain fields. J Neurophysiol 1997, 77(6):3267-3272.

6. Apps R: Movement-related gating of climbing fibre input to cerebellar cortical zones. Prog Neurobiol 1999, 57(5):537-562.

7. Porrill J, Dean P: Silent synapses, LTP and the indirect parallel-fibre pathway: computational consequences of optimal noise processing. PLOS Comput Biol 2008, 4(5):e1000085.

8. Fernandez FR, Engbers JD, Turner RW: Firing dynamics of cerebellar purkinje cells. J Neurophysio/ 2007, 98(1):278-294.

doi:10.1186/1471-2202-11-S1-P146

Cite this article as: Engbers et al:: Climbing-fiber induced state transitions in cerebellar Purkinje cells are controlled by synaptic conductance changes. BMC Neuroscience 2010 11(Suppl 1):P146.

\section{Submit your next manuscript to BioMed Central} and take full advantage of:

- Convenient online submission

- Thorough peer review

- No space constraints or color figure charges

- Immediate publication on acceptance

- Inclusion in PubMed, CAS, Scopus and Google Scholar

- Research which is freely available for redistribution

Submit your manuscript at www.biomedcentral.com/submit
C Biomed Central 